\begin{tabular}{|l|l|l||}
\hline \multicolumn{2}{|c|}{ PublisherInfo } \\
\hline \hline PublisherName & $:$ & BioMed Central \\
\hline \hline PublisherLocation & $:$ & London \\
\hline \hline PublisherImprintName & $:$ & BioMed Central \\
\hline \hline
\end{tabular}

\title{
Viruses on the brain
}

\begin{tabular}{|l|l|l||}
\hline \multicolumn{2}{|c|}{ ArticleInfo } \\
\hline \hline ArticleID & $:$ & 4402 \\
\hline \hline ArticleDOI & $:$ & $10.1186 /$ gb-spotlight-20020215-01 \\
\hline \hline ArticleCitationID & $:$ & spotlight-20020215-01 \\
\hline \hline ArticleSequenceNumber & $:$ & 68 \\
\hline \hline ArticleCategory & $:$ & Research news \\
\hline ArticleFirstPage & $:$ & 1 \\
\hline \hline ArticleLastPage & $:$ & 2 \\
\hline \hline & & RegistrationDate : 2002-2-15 \\
\hline ArticleHistory & $:$ & OnlineDate \\
\hline \hline ArticleCopyright & $:$ & BioMed Central Ltd2002-15 \\
\hline \hline ArticleGrants & $:$ & \\
\hline \hline ArticleContext & $:$ & 130593311 \\
\hline \hline
\end{tabular}




\section{Jonathan B Weitzman}

Email: jonathanweitzman@hotmail.com

The ability to selectively delete genes in specific neuronal cell types in mice enhances the study of complex brain functions, behavioural traits, and neurodegenerative diseases. In the February 19 Proceedings of the National Academy of Sciences, Brain Kaspar and researchers at The Salk Institute in California, describe a viral delivery system that could prove effective for tissue-specific gene ablation in adult mice (Proc Natl Acad Sci USA 2002, 99:2320-2325). They chose adeno-associated virus (AAV) as a gene delivery vector, as it exhibits low toxicity and immunogenicity, and stable gene expression in the nervous system. They developed an AAV construct encoding green fluorescent protein (GFP) fused to a nuclear localization signal and the Cre recombinase (AAV-GFP/Cre). They then used a reporter transgenic mouse that expresses $\beta$-galactosidase upon Cre-induced recombination. The mice were injected with AAV-GFP/Cre particles in the hippocampus, striatum, septum or substantia nigra. Kaspar et al., found evidence for recombination in different neuronal cells in these brain regions after seven days; they saw no effects on cytotoxicity or the immune response. This system offers an alternative to the lengthy process of generating and breeding transgenic mouse lines to achieve temporal and spatial conditional gene modification.

\section{References}

1. Molecular genetic analysis of synaptic plasticity, activity-dependent neural development, learning, and memory in the mammalian brain.

2. Proceedings of the National Academy of Sciences, [http://www.pnas.org]

3. The Salk Institute, [http://www.salk.edu]

4. Long-term gene expression and phenotypic correction using adeno-associated virus vectors in the mammalian brain. 